\title{
Early corticosteroid initiation delays viral RNA clearance in respiratory secretions of COVID-19 patients
}

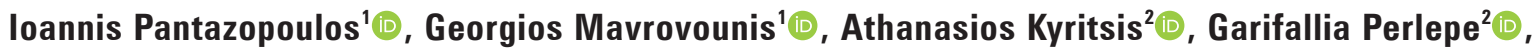 \\ Angeliki Miziou² $^{2}$, Konstantinos Gourgoulianis ${ }^{2}$ (D)
}

'Department of Emergency Medicine, University of Thessaly, Faculty of Medicine, Biopolis, Greece

${ }^{2}$ Department of Respiratory Medicine, University of Thessaly, Medical School, University General Hospital of Larisa, Biopolis, Greece

\section{To the Editor}

Previous studies have demonstrated that a cumulative dose of methylprednisolone more than $200 \mathrm{mg}$ could suppress the immune cells resulting in prolonged severe acute respiratory syndrome coronavirus 2 shedding in patients with coronavirus disease 2019 (COVID-19) pneumonia $[1,2]$. In our study, we further confirm an association between early corticosteroid use and delayed viral shedding in COVID-19 patients.

In Greece, in contrast to current guidelines, many doctors in fear of the "cytokine storm" and in the absence of other drugs for the treatment of COVID-19, prescribed corticosteroids for "out-of-hospital" use (early initiation) in febrile patients with normal saturation of oxygen $\left(\mathrm{SpO}_{2}\right)$ and no evidence of pneumonia [3].

We reviewed the records of patients with early corticosteroid initiation that were later admitted to a tertiary, University hospital, the largest public reference unit in Thessaly, Greece with COVID-19 pneumonia and those of patients with late corticosteroid initiation (in-hospital initiation of corticosteroids if hypoxemia was present, according to current guidelines) [3]. Early versus late corticosteroid treated patients were propensity score matched to adjust for baseline differences.

We measured the time from COVID-19 onset to two consecutive reverse transcription poly- merase chain reaction (RT-PCR) negative tests with Kaplan-Meier graphs and compared the duration of viral shedding between early and late corticosteroids treatment group with log-rank tests. The virus clearance time was calculated from the onset of symptoms to the date of the first negative RT-PCR test. Furthermore, we compared ICU admission rates and hospital length of stay in both groups. A total of 64 COVID-19 patients were included in the study and the mean age was $57.83 \pm 12.66$ years. Among them, 32 patients were given early home corticosteroid treatment and 32 were given corticosteroids during hospitalization due to hypoxemia $\left(\mathrm{SpO}_{2}<94 \%\right)$. All patients received dexamethasone in a dose of $6 \mathrm{mg}$ per day for a 10-day period (total $60 \mathrm{mg}$ ). Patients' characteristics are shown in Table 1. All patients had a $\mathrm{PaO}_{2} / \mathrm{FiO}_{2}$ ratio $>200$ at admission. A difference of 5.5 days in viral shedding was observed between the early and late corticosteroid initiation group as shown in Figure 1. No difference was observed in ICU admissions and hospital length of stay.

Our data demonstrates that apart from a high cumulative dose, early corticosteroid use delays viral clearance in COVID-19 patients. Further larger studies are needed to identify if this delay is associated with worse outcomes.

\section{Conflict of interest}

None declared. 
Table 1. The basic characteristics of the patients in both groups

\begin{tabular}{|c|c|c|c|}
\hline & $\begin{array}{l}\text { Early dexamethasone } \\
\text { group }(n=32)\end{array}$ & $\begin{array}{l}\text { Late dexamethasone } \\
\text { group ( } \mathrm{n}=32 \text { ) }\end{array}$ & P-value \\
\hline Mean age $\pm S D$ & $55.7 \pm 11.7$ & $60 \pm 13.4$ & 0.17 \\
\hline $\begin{array}{l}\text { Symptoms on admission } \\
\text { Dyspnea (\%) } \\
\text { Cough (\%) } \\
\text { Anosmia/ageusia (\%) } \\
\text { Myalgias/weakness (\%) }\end{array}$ & $\begin{array}{c}37.50 \\
75 \\
18.75 \\
81.25\end{array}$ & $\begin{array}{l}37.50 \\
65.63 \\
18.75 \\
46.88\end{array}$ & $\begin{array}{c}>0.99 \\
0.59 \\
>0.99 \\
0.009\end{array}$ \\
\hline $\begin{array}{l}\text { Admission vital signs } \\
\text { Mean temperature } \pm \text { SD } \\
\text { Mean P/F ratio } \pm \text { SD } \\
\text { Median respiratory rate (IQR) } \\
\text { Median systolic blood pressure (IOR) } \\
\text { Median heart rate (IQR) }\end{array}$ & $\begin{array}{c}37.6 \pm 0.56 \\
291.6 \pm 69 \\
22(20-25) \\
129.5(120-136) \\
82(77.25-91)\end{array}$ & $\begin{array}{c}37.5 \pm 0.76 \\
277.5 \pm 33.4 \\
20(19.25-22) \\
119(110.3-125) \\
86(76-93.5)\end{array}$ & $\begin{array}{c}0.63 \\
0.30 \\
0.06 \\
<0.001 \\
0.54\end{array}$ \\
\hline $\begin{array}{l}\text { Treatment in hospital } \\
\text { Dexamethasone (\%) }\end{array}$ & 100 & 100 & $>0.99$ \\
\hline $\begin{array}{l}\text { Median duration of viral shedding } \\
\text { [days] }\end{array}$ & 27.50 & 22 & $\begin{array}{l}\text { Log-rank (Mantel-Cox) test: } \\
\text { chi square }=13.44, p \text {-value }<0.001\end{array}$ \\
\hline $\begin{array}{l}\text { Outcomes } \\
\text { ICU admission (\%) } \\
\text { In-hospital mortality (\%) }\end{array}$ & $\begin{array}{l}0 \\
0\end{array}$ & $\begin{array}{l}9.38 \\
6.25\end{array}$ & $\begin{array}{l}0.24 \\
0.49\end{array}$ \\
\hline
\end{tabular}

ICU — intensive care unit; IQR — interquartile range; SD — standard deviation

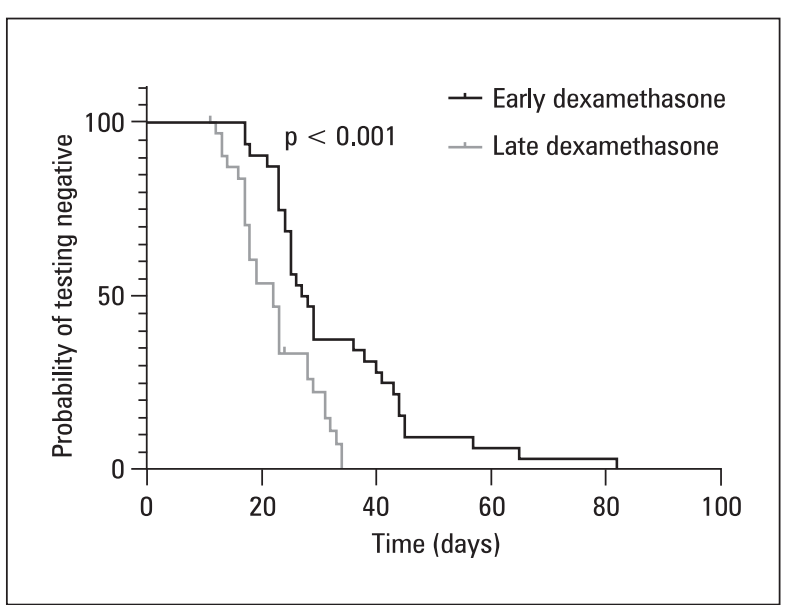

Figure 1. Kaplan-Meier presenting the comparison of days to test negative

\section{References:}

1. Cao HR, Zhu XY, Zhou L, et al. Factors associated with delayed viral shedding in COVID-19 infected patients: A retrospective small-scale study. Respir Med. 2021; 178: 106328, doi: 10.1016/j.rmed.2021.106328, indexed in Pubmed: 33588209.

2. Tang X, Feng YM, Ni JX, et al. Early use of corticosteroid may prolong SARS-CoV-2 shedding in non-intensive care unit patients with COVID-19 pneumonia: a multicenter, single-blind, randomized control trial. Respiration. 2021; 100(2): 116-126, doi: 10.1159/000512063, indexed in Pubmed: 33486496.

3. National Institute of Health, COVID-19 Treatment guidelines. https://www.covid19treatmentguidelines.nih.gov/overview/ clinical-spectrum/ (July 4, 2021). 